\title{
Vegetable pigments in sorghum-based diets for laying hens
}

\author{
Donaldo Antônio Nunes Junior ${ }^{1}$; Heder José D’Avila Lima ${ }^{2}$; Jean Kaique Valentim ${ }^{3 *}$; Laura Aline Zanelatto \\ de Souza ${ }^{4}$; Nayara Emanoelle Matos e Silva ${ }^{5}$; Ana Carolina da Silva Martins ${ }^{6}$, Tatiana Marques Bittencourt ${ }^{7}$, \\ Janaína Palermo Mendes ${ }^{8}$
}

DOI: https://doi.org/10.35699/2447-6218.2020.24309

\begin{abstract}
The main objective of this research is to evaluate the inclusion of different natural pigment solutions in diets formulated with maize and sorghum solutions on the growth performance and egg quality of commercial laying hens created in hot climates. Throughout the conduction of this experiment, were used 252 laying hens of the Hisex Brow, in a completely randomized design, with six treatments, seven repetitions, and six birds per plot. The experimental diets were assigned with different energy sources and adding pigmentation solutions, diet 1 (corn), diet 2 (corn + annatto), diet 3 (corn + carrot), diet 4 (sorghum), diet 5 (sorghum + annatto), diet 6 (sorghum + Carrot). Afterward, being evaluated the performance and quality of eggs. It was observed significant difference with reference t egg production, egg weight (g), gem weight $(\mathrm{g})$, the weight of shell $(\mathrm{g})$, albumin in weight $(\mathrm{g})$, and gem coloration (tons) among the treatments. There was no difference in the parameters of performance and quality of eggs evaluated, only the variable yolk color had a significant effect between treatments. Replacing the energy source of the corn diet with sorghum in the diet of laying hens at peak production provides similar performance and egg quality, which can be a substitute for quality and efficiency. The use of annatto and carrots as a natural pigmentation promotes greater pigmentation of the egg yolks of laying Hisex Brown eggs and does not impair the performance of the birds.
\end{abstract}

Keywords: Annatto. Carrot. Egg Yolk. Plant extracts. Poultry Science.

\section{Pigmentantes vegetais em dietas à base de sorgo para galinhas poedeiras}

\section{Resumo}

O principal objetivo desta pesquisa foi avaliar a inclusão de diferentes fontes pigmentantes naturais em dietas formuladas a base de milho e sorgo sobre o desempenho produtivo e a qualidade dos ovos de galinhas poedeiras comerciais criadas em clima quente. Ao longo da condução deste experimento, foram utilizadas 252 poedeiras da linhagem Hisex Brow, distribuídas em um delineamento inteiramente casualizado, com seis tratamentos, sete repetições e seis

${ }^{1}$ Universidade Federal do Mato Grosso. Cuiabá, MT. Brasil.

https://orcid.org/0000-0002-0365-9287

${ }^{2}$ Universidade Federal dos Vales do Jequitinhonha e Mucuri. Diamantina, MG. Brasil. https://orcid.org/0000-0002-8360-8227

${ }^{3}$ Universidade Federal da Grande Dourados. Dourados, MS. Brasil.

https://orcid.org/0000-0001-8547-4149

${ }^{4}$ Universidade Federal do Mato Grosso. Cuiabá, MT. Brasil.

https://orcid.org/0000-0002-7663-5331

${ }^{5}$ Universidade Federal do Mato Grosso. Cuiabá, MT. Brasil.

https://orcid.org/0000-0002-5957-9032

6Universidade Federal do Mato Grosso. Cuiabá, MT. Brasil.

https://orcid.org/0000-0002-3177-3642

${ }^{7}$ Universidade Federal do Mato Grosso. Cuiabá, MT. Brasil.

https://orcid.org/0000-0002-2941-2039

8Universidade Federal da Grande Dourados. Dourados, MS. Brasil. https://orcid.org/0000-0002-7860-0933

*Autor para correspondência: kaique.tim@hotmail.com

Recebido para publicação em 26 de Julho de 2020. Aceito para publicação 25 de Outubro de 2020.

e-ISSN: 2447-6218 / ISSN: 2447-6218. Atribuição CC BY. 
aves por parcela. Foram utilizadas diferentes fontes energéticas com adição de dois pigmentantes naturais, dieta 1 (milho), dieta 2 (milho + urucum), dieta 3 (milho + cenoura), dieta 4 (sorgo), dieta 5 (sorgo + urucum), dieta 6 (Sorgo + Cenoura). Posteriormente, foram avaliados o desempenho e a qualidade dos ovos. Foi observada diferença significativa com relação à produção de ovos de referência, peso do ovo $(\mathrm{g})$, peso da gema $(\mathrm{g})$, peso da casca $(\mathrm{g})$, peso da albumina (g) e coloração da gema entre os tratamentos. Não houve diferença nos parâmetros de desempenho e qualidade dos ovos avaliados, apenas a variável cor da gema teve efeito significativo entre os tratamentos. A substituição da fonte de energia da dieta de milho por sorgo na dieta de poedeiras em pico de produção proporciona desempenho e qualidade do ovo semelhantes, o que pode ser um substituto para qualidade e eficiência. O uso de urucum e cenoura como pigmentação natural promove maior pigmentação das gemas de ovos de postura dos ovos Hisex Brown e não prejudica o desempenho das aves.

Palavras-chave: Cenoura. Ciência Avícola. Extratos de plantas. Urucum. Gema de ovo.

\section{Introduction}

In the current scenario poultry farming stands out as one of the largest markets to be explored in Brazil, both for its export value and domestic consumption. To leverage this growth, measures that encourage consumers to consume eggs are essential. In poultry food, the use of additives and by-products is responsible for significant gains in productivity in the sector (Araújo et al., 2007).

The supplementation of pigments in diets for commercial laying hens formulated with sorghum is done seeking to improve the pigmentation of egg yolk, being an important tool to adjust this coloration to be similar and / or superior when using corn-based diets (Mendonça et al., 2018).

To favor this niche market, the poultry industry uses products to increase the coloring of the yolks of these eggs, through the addition of carotenoid compounds that are abundantly found in nature, such as those present in the corn itself, main input in poultry rations (Bazaka et al., 2016). The color of the egg yolk is given through the deposition of xanthophylls, carotenoid pigments derived from the feed of the birds (Marounek et al., 2018). There are several foods with high concentrations of carotenoids, such as corn and millet, among others, but there are also foods with low concentrations of carotenoids, such as sorghum (Fayeye et al., 2019).

According to Valentim et al. (2019) the substitution of synthetic pigments by natural pigments can be a viable alternative in laying poultry, as it does not affect the productive performance of laying hens. Due to health risks and their cost, artificial pigments are being less used, favoring the use of natural substances (Pereira et al., 2016).

Thus, the objective of this research is to analyze the inclusion of different natural pigments in corn-based diets and sorgo on zootechnical performance and the quality of commercial laying hen eggs during peak laying.

\section{Material and methods}

The experiment was carried out in the Poultry Sector of the Experimental Farm of the Federal University of Mato Grosso, located in the municipality of Santo Antônio de Leverger - MT. The experimental shed used was masonry, with a right foot height of $3.5 \mathrm{~m}$, ceramic tile roof, side, and central concreted flooring, sidewalls with external protection of steel screen, and equipped with fans and lamps.

A totalizes of the 252 laying hens of the lineage Hisex Brown lineage was used, 25 weeks old, the initial weight of $1.566 \pm 0.180(\mathrm{Kg})$, and production rate of 88 $\pm 5 \%$. The laying hens were distributed in an experimental design entirely randomized, consisting of six diets and seven replicates, with six laying hens each. The lighting program adopted was 16 hours of daylight.

Galvanized wire cages with dimensions of $100 \mathrm{~cm}$ $\mathrm{x} 40 \mathrm{~cm}$ were used, containing 3 breakdowns of $33.3 \mathrm{~cm} \mathrm{x}$ $40 \mathrm{~cm}$, housing two laying hens per distribution, providing an area of $800 \mathrm{~cm}^{2} /$ bird, arranged in stairs, equipped with a gutter feeder and nipple drinker, in the disposal of a drinking fountain for two laying hens.

The mean air temperature in the experimental period was $32.4 \pm 2.88^{\circ} \mathrm{C}$ and the relative humidity was $61 \pm 18.9 \%$. The nutritional requirements used for the formulation of poultry feed and the chemical composition and nutritional values of the ingredients used for the formulation of the rations were those described by Rostagno et al. (2017). The centesimal composition of foods used as a source of natural pigments and energy in diets for laying hens are presented in Table 1.

Five isocaloric and isonitrogenous experimental diets were formulated based on corn, sorgo, and soybean meal with inclusion levels of equal pigments, but from different sources (annatto and carrot flour), 0.5\% level of inclusion in the diet according to the table 2 . 
Table 1 - Centesimal composition of food

\begin{tabular}{lccccccc}
\hline \multicolumn{1}{c}{ Food } & $\begin{array}{c}\text { Moisture } \\
(\mathbf{\%})\end{array}$ & $\begin{array}{c}\text { Metabolizable } \\
\text { Energy (Kcal) }\end{array}$ & $\begin{array}{c}\text { Crude Pro- } \\
\text { tein }(\mathbf{g})\end{array}$ & $\begin{array}{c}\text { Lipids } \\
\mathbf{( g )}\end{array}$ & $\begin{array}{c}\text { Carbohydrates } \\
(\mathbf{g})\end{array}$ & $\begin{array}{c}\text { Raw Fi- } \\
\text { ber } \mathbf{( g )}\end{array}$ & $\begin{array}{c}\text { Ashes } \\
(\mathbf{g})\end{array}$ \\
\hline Annatto & 5.32 & 3484 & 10.87 & 17.09 & 60.40 & 3.57 & 2.75 \\
Carrot & 90.01 & 3400 & 1.30 & 0.20 & 7.75 & 3.22 & 0.90 \\
Corn & 11.57 & 3925 & 7.20 & 1.95 & 78.98 & 4.73 & 0.61 \\
Sorghum & 10.21 & 3928 & 11.71 & 3.47 & 61.2 & 11.4 & 1.53 \\
\hline
\end{tabular}

Source-Table of Brazilian food composition (2011).

Table 2 - Percentage and calculated composition of experimental diets based on natural matter.

\begin{tabular}{|c|c|c|c|c|c|c|}
\hline Ingredients (\%) & Corn & $\begin{array}{c}\text { Corn } \\
+ \\
\text { Annatto }\end{array}$ & $\begin{array}{c}\text { Corn } \\
+ \\
\text { Carrot }\end{array}$ & Sorghum & $\begin{array}{c}\text { Sorghum } \\
+ \\
\text { Annatto }\end{array}$ & $\begin{array}{c}\text { Sorghum } \\
+ \\
\text { Carrot }\end{array}$ \\
\hline Ground corn \% & 62.0 & 61.3 & 61.25 & - & - & - \\
\hline Sorghum \% & - & - & - & 61.6 & 61.1 & 60.9 \\
\hline Starch \% & 0.5 & 0.70 & 0.75 & 1.9 & 1.9 & 2.0 \\
\hline Soybean Meal \% & 25.0 & 25.0 & 25.0 & 24.0 & 24.0 & 24.10 \\
\hline Core $\%$ & 1.5 & 1.5 & 1.5 & 1.5 & 1.5 & 1.5 \\
\hline Dicalcium phosphate \% & 7.6 & 7.6 & 7.6 & 7.6 & 7.6 & 7.6 \\
\hline Limestone \% & 1.1 & 1.1 & 1.1 & 1.1 & 1.1 & 1.1 \\
\hline Common salt $\%$ & 0.5 & 0.5 & 0.5 & 0.5 & 0.5 & 0.5 \\
\hline Soybean oil \% & 1.8 & 1.8 & 1.8 & 1.8 & 1.8 & 1.8 \\
\hline Carrot flour $\%$ & - & - & 0.5 & - & - & 0.5 \\
\hline Annatto \% & 0.0 & 0.5 & - & - & 0.5 & - \\
\hline
\end{tabular}

\section{Calculated Nutritional Composition}

\begin{tabular}{lcccccc}
\hline Metabolizable energy (Kcal/Kg) & 2900 & 2900 & 2900 & 2900 & 2900 & 2900 \\
Crude protein \% & 16.02 & 16.02 & 16.02 & 16.02 & 16.02 & 16.02 \\
Calcium \% & 3.90 & 3.90 & 3.90 & 3.90 & 3.90 & 3.90 \\
Match available \% & 0.291 & 0.291 & 0.291 & 0.291 & 0.291 & 0.291 \\
Sodium \% & 0.218 & 0.218 & 0.218 & 0.218 & 0.218 & 0.218 \\
Digestible Lysine \% & 0.777 & 0.777 & 0.777 & 0.777 & 0.777 & 0.777 \\
Digestible Methionine \% & 0.389 & 0.389 & 0.389 & 0.389 & 0.389 & 0.389 \\
Methionine Cystine \% & 0.707 & 0.707 & 0.707 & 0.707 & 0.707 & 0.707 \\
Digestible Threoin \% & 0.591 & 0.591 & 0.591 & 0.591 & 0.591 & 0.591 \\
Tryptophan \% & 0.179 & 0.179 & 0.179 & 0.179 & 0.179 & 0.179 \\
\hline
\end{tabular}

Guarantee levels per kg of core, Calcium (max) 210g, Calcium (min) 170g, Phosphorus (min) 45g, Methionine (min) 10g. Vitamin A (min) 140,000 U.I.,Vitamin D3 (min) 35,000 U.I.,Vitamin E (min) 140 U.I., Thiamine (B1) (min) 10 mg, Riboflavin (B2) (min) 75 mg, Pyridoxine (B6) (min) 20 mg, Vitamin B12 (min) 120 mcg, Vitamin K3 (mini) $30 \mathrm{mg}$, Folic Acid (min) $6 \mathrm{Mg}$, Niacin (mini) $300 \mathrm{mg}$, Calcium Pantothenate (min) $120 \mathrm{mg}$, Choline (min) $5000 \mathrm{mg}$, Sodium (min) 30g, Manganese (min) $1600 \mathrm{mg}$, Zinc (min) $1300 \mathrm{mg}$, Copper (min) $160 \mathrm{mg}$, Iron (min) $630 \mathrm{mg}$, Iodo (min) 20 mg, Selenium (min) 6 mg, Phytase (min) 10,000 FTU and Zinc Bacitracin 500 Mg.

The experiment was carried out in 3 periods of 21 days, totaling 63 days, the diet consumption was calcula- ted by the difference between the quantity provided and the leftovers, correcting possible mortality in the plots. 
Nunes Junior, D. A. et al.

The eggs were collected daily in the afternoon and the average egg production was obtained by computing the number of eggs produced, including broken, cracked, and abnormal ones and was expressed as a percentage, on the average laying hens of the period (egg/bird/day).

All healthy eggs produced during the three experimental days, in each repetition were weighed in the precision scale of $0.01 \mathrm{~g}$ and the total weight obtained was divided by the number of eggs used in the weighing, obtaining the average weight of the eggs.

To evaluate the egg components, the weights of the yolk, shell, and albumen were analyzed about egg weight and yolk staining. For this, in each period of analysis, 3 eggs of each experimental unit were randomly used. The eggs were weighed individually in scale swings with an accuracy of $0.01 \mathrm{~g}$. The yolk of each egg was weighed and recorded using the digital photography method and colorimetric range DSM 14 tones, which varies between opaque yellow and intense orange, the higher the value obtained in the fan, the higher the degree of yolk pigmentation. Their respective shells were washed and dried into the air for two days to obtain the weight of the bark.

The weight of the album was obtained by subtracting from the weight of the egg, the weight of the yolk, and that of the shell. Food conversions were evaluated by dozen eggs, expressed by the total feed intake in kilograms divided by the dozens of eggs produced (Kg/DZ). All laying hens were weighed at the beginning and end of the experiment to determine body weight variation. The specific severity was determined by the saline fluctuation method, according to the methodology described by Hamilton (1982).

The specific severity of all healthy eggs collected was evaluated. The eggs were immersed in $\mathrm{NaCl}$ solution with density ranging from 1.070 to $1.1000 \mathrm{~g} / \mathrm{cm}^{3}$, with intervals of $0.005 \mathrm{~g} / \mathrm{cm}^{3}$ between them. The density of the solutions was measured with the aid of an INCOTERM-OM-5565 model densimeter.

The data obtained were analyzed using the Statistical Analysis System (SAS, 2012) statistical package, and the normality of the residues was verified using the Shapiro-Wilk test and the variances compared by the Levenes Test. Subsequently, the data were submitted to variance analysis by the Mixed procedure (PROC MIXED) using the Tukey test at the level of 5\% significance.

\section{Results and Discussion}

No significant effect $(\mathrm{p}<0.05)$ was observed on feed intake, egg production, and feed conversion by mass and by dozen of laying hens as a function of diets (Table $3)$.

Table 3 - Performance of laying hens fed different natural pigments in two energy sources

\begin{tabular}{lcccccccc}
\hline Parameters & Corn & $\begin{array}{c}\text { Corn } \\
+ \\
\text { Annatto }\end{array}$ & $\begin{array}{c}\text { Corn } \\
+ \\
\text { Carrot }\end{array}$ & Sorghum & $\begin{array}{c}\text { Sorghum } \\
+ \\
\text { Annatto }\end{array}$ & $\begin{array}{c}\text { Sorghum } \\
+ \\
\text { Carrot }\end{array}$ & CV (\%) & P-value \\
\hline $\begin{array}{l}\text { Feed consumption } \\
\text { (g/bird/day) }\end{array}$ & 85.08 & 86.15 & 84.82 & 82.25 & 83.28 & 82.79 & 7.50 & 0.087 \\
$\begin{array}{l}\text { Egg production (\%) } \\
\begin{array}{l}\text { Feed conversion by } \\
\text { mass }\end{array}\end{array}$ & 88.87 & 89.78 & 90.14 & 89.78 & 90.73 & 88.25 & 9.25 & 0.0589 \\
$\begin{array}{l}\text { Feed conversion per } \\
\text { dozen }\end{array}$ & 1.89 & 1.98 & 1.95 & 2.01 & 1.97 & 2.02 & 8.21 & 0.145 \\
$\begin{array}{l}\text { Viability of laying } \\
\text { hens (\%) }\end{array}$ & 98 & 100 & 100 & 99 & 100 & 99 & 0 & 0.189 \\
\hline
\end{tabular}

Media followed by the same letter in the line do not differ from each other at the level of $5 \%$ significance by the Tukey test (p<0.05). CV: Coefficient of Variation.

As reported by Botelho et al., (2017) it is possible to completely replace corn with low tannin sorghum in the diet of commercial laying hens without interfering in the productive characteristics of zootechnical performance. The use of alternative ingredients to corn in feed, in addition to a need to reduce costs in egg production, is an opportunity to find other energy sources that replace corn, without harming animal performance (Bittencourt et al., 2019).
This fact can be explained by the nutritional composition of the ingredients tested, and due to the diets used to be isonutritive, with this, the laying hens presented similar zootechnical performance. Molino et al. (2012) working with annatto in diets based on sorgo and soybean meal, also found no effects on the consumption of laying hens from the Hisex Brown lineage. On the other hand, Queiroz et al. (2010) observed a difference in feed intake when the amount of pigmented inclusion exceeded $6 \%$ in the sorgo-based diet. 
Vegetable pigments in sorghum-based diets for laying hens

Valentim et al. (2019) and Boka et al. (2014) found that plant extracts have a positive effect because of its antioxidant activity which improves nutrient digestibility and stimulates enzyme secretion, helping to preserve intestine microbiota, impacting on better feed conversion, production and egg's internal quality.

Analyzing the data for egg production, no significant difference was observed in diets, and productivity values indicated a higher production with diets containing sorgo in place of corn. Moreno et al. (2007), evaluating the partial and total replacement of corn by sorgo in laying hen diets, observed that the substitution caused a decrease in production, which differs from the result found in the present study.

The color of the egg yolk showed differences between treatments $(\mathrm{p}<0.05)$, the other variables did not show differences between the means, as shown in table 4.

Table 4 - Quality of laying bird eggs fed different natural pigments in two energy sources

\begin{tabular}{|c|c|c|c|c|c|c|c|c|}
\hline Parameters & Corn & $\begin{array}{c}\text { Corn } \\
+ \\
\text { Annatto }\end{array}$ & $\begin{array}{c}\text { Corn } \\
+ \\
\text { Carrot }\end{array}$ & $\begin{array}{c}\text { Sorghum } \\
+ \\
\text { Annatto }\end{array}$ & $\begin{array}{l}\text { Sor- } \\
\text { ghum }\end{array}$ & $\begin{array}{c}\text { Sorghum } \\
+ \\
\text { Carrot }\end{array}$ & $\begin{array}{l}\text { CV } \\
(\%)\end{array}$ & P-value \\
\hline Egg weight (g) & 50.29 & 51.48 & 51.25 & 51.55 & 50.59 & 50.78 & 8.25 & 0.256 \\
\hline Specific gravity $\left(\mathrm{g} / \mathrm{cm}^{3}\right)$ & 1.092 & 1.090 & 1.091 & 1.091 & 1.092 & 1.090 & 2.48 & 0.478 \\
\hline Yolk weight (g) & 12.21 & 12.87 & 12.25 & 12.80 & 12.12 & 12.57 & 7.47 & 0.087 \\
\hline Hull weight (g) & 4.98 & 4.76 & 5.01 & 4.99 & 4.55 & 4.89 & 10.1 & 0.078 \\
\hline Weight of albumen $(\mathrm{g})$ & 33.54 & 32.11 & 33.52 & 31.14 & 30.45 & 32.80 & 2.54 & 0.066 \\
\hline Yolk pigmentation & $5.29^{\mathrm{b}}$ & $6.78^{\mathrm{a}}$ & $6.11^{\mathrm{a}}$ & $3.08^{\mathrm{c}}$ & 1.45 & $3.01^{\mathrm{c}}$ & 8.78 & 0.014 \\
\hline
\end{tabular}

Media followed by the same letter in the line do not differ from each other at the level of $5 \%$ significance by the Tukey test (p<0.05). CV: Coefficient of Variation.

There was no difference in the parameters of performance and quality of eggs evaluated, only the variable yolk color had a significant effect between treatments.

Therefore, the replacement of corn with low tannin sorghum in the diet of laying hens in peak production does not affect the performance and quality of eggs, which may be a substitute source in poultry production. However, sorghum without pigmentation supplementation provides a smaller yolk color. Thus, the addition of natural pigment sources is indicated in the diet, due to consumer preference for more vibrant colored eggs.

Adding plant extracts pigments in quails' feed did not change egg quality but improves yolk color due to the higher deposition of carotenoid pigments (Valentim et al., 2020). What may be correlated with egg weight, which was also higher in these same treatments. Moreno et al. (2007), found a significant difference for yolk weight when the replacement of the corn and sorgo energy source was $100 \%$.

When the yolk staining was evaluated, a significant difference was observed, and diet 2 (Corn + Annatto) provided pigmentation greater than the others, according to observation through the colorimetric range. The largest discrepancy was verified between diets 1 (corn), 2 (Corn + Annatto), 3 (Corn + Carrot) when compared with diets 4 (Sorgo), 5 (Sorgo + Annatto), and 6 (Sorgo + Carrot), due to total corn replacement by sorgo. These results corroborate Braz et al. (2007), who found a significant difference when corn was completely replaced by sorgo and report that to obtain similarity in staining it was necessary to include approximately $3.77 \%$ of annatto in a diet containing sorgo as the main source of energy. Sorghum in laying diets can have advantages, as it is sold at a price of around $80 \%$ of the price of corn, despite the nutritional differences between them (Fassani et al., 2019).

Englmaierová et al. (2014) mentioned that synthetic pigments are used because of its coloring effect of yolk but the use should be limited. Natural alternatives give the same coloring result when choosing eggs, without hurting egg quality and human health.

Moraleco et al. (2019) Regarding egg and shell weight as well as shell percentage there were no significant effects ( $p>0.05)$, these results are in agreement with those reported by Galobart et al. (2004), which suggested that natural extracts do not influence animal performance and the quality of the eggs. Moura et al. (2011) demonstrated the ability of pigmentation of these additives while working with the inclusion of natural pigments in the sorghum-based diet fed to Japanese quail and observed incremental potentializing of the color evaluated using a colorimetric score.

The addition of pigmented plant extracts was not able to change the internal and external quality of the eggs, however there was an improvement in the yolk color due to the higher deposition of pigmenting carotenoids. 


\section{Conclusion}

Replacing the energy source of the corn diet with sorghum in the diet of laying hens at peak production provides similar performance and egg quality, which can be a substitute for quality and efficiency. The use of annatto and carrots as a natural pigmentation promotes greater pigmentation of the egg yolks of laying Hisex
Brown eggs and does not impair the performance of the birds.

\section{Ethics Committee approval}

The project was submitted, analyzed, and approved by the ethics committee in the use of animals (CEUA), filed under number 23108.092960/ 2015-80.

\section{References}

Araujo, J. A., da Silva, J. H. V., de Lima Amâncio, A. L., de Lima, M. R., \& Lima, C. B. 2007. Uso de aditivos na alimentação de aves. Acta Veterinaria Brasílica, 1(3): 69-77. Doi: https://doi.org/10.21708/ avb.2007.1.3.488.

Bazaka, Kateryna; Jacob, Mohan V.; Ostrikov, Kostya. 2016. Sustainable life cycles of natural-precursor-derived nanocarbons. Chemical reviews, 116 (1): 163-214. Doi: https://pubs.acs.org/doi/abs/10.1021/acs. chemrev.5b00566.

Bittencourt, T. M., Lima, H. J. D. A., Valentim, J. K., Martins, A. C. D. S., Moraleco, D. D., \& Vaccaro, B. C. 2019. Distillers dried grains with solubles from corn in diet of japanese quails. Acta Scientiarum. Animal Sciences, 41. https://doi.org/10.4025/actascianimsci.v41i1.42749.

Botelho, L. F. R., Maciel, M. P., Silva, M. L. F., Reis, S. T., Alves, E. E., Aiura, F. S., ... \& Silva, D. B. 2017. Níveis de açafrão (Curcuma longa) em rações para frangos de corte contendo sorgo em substituição ao milho. Archivos de zootecnia, 66 (253), 35-43. https://doi.org/10.21071/ az.v66i253.2123.

Boka, J., Mahdavi, A. H., Samie, A. H., \& Jahanian, R. 2014. Effect of different levels of black cumin (Nigella sativa L.) on performance, intestinal E scherichia coli colonization and jejunal morphology in laying hens. Journal of animal physiology and animal nutrition, 98 (2): 373-383. Doi: https://doi.org/10.1111/jpn.12109.

De Mendonça, A. S. A., Correa, R. E. A., Benevides, P. R., Mota, A. V., \& De Abreu Franca, E. B. 2018. Pigmentante alternativo para gema em ovos de galinha caipira no município de Garrafão-do-Norte/PA. Cadernos de Agroecologia, 13(2), 10-10. http://cadernos.aba-agroecologia.org. br/index.php/cadernos/article/view/2127.

Englmaierová, M., Bubancová, I., \& Skřivan, M. Carotenoids and egg quality. 2014. Acta Fytotechnica et Zootechnica, 17 (2): 55-57. Doi: http://doi: 10.15414 / afz.2014.17.02.55-57.

Fassani, E. J., Abreu, M. T., \& Silveira, M. M. B. M. (2019). Coloração de gema de ovo de poedeiras comerciais recebendo pigmentante comercial na ração. Ciência Animal Brasileira, 20. https://doi.org/10.1590/10896891v20e-50231.

Galobart, J., Sala, R., Rincón-Carruyo, X., Manzanilla, E., Vila, B., \& Gasa, J. 2004. Egg yolk color as affected by saponification of different natural pigmenting sources. Journal of Applied Poultry Research, 13 (2): 328-334. Doi: http://doi: 10.1093/japr/13.2.328.

Marounek, M., \& Pebriansyah, A. 2018. Use of carotenoids in feed mixtures for poultry: a review. Agricultura Tropica et Subtropica, 51(3), 107-111. https://doi.org/10.2478/ats-2018-0011.

Melo Braz, N., Fuentes, M. D. F. F., Freitas, E. R., Sucupira, F. F., Moreira, R. F., \& Lima. 2007. Semente residual do urucum na alimentação de poedeiras comerciais: desempenho e características dos ovos. Acta Scientiarum. Animal Sciences, 29 (2): 1-10. Doi: https://doi. org/10.4025/actascianimsci.v29i2.207.
Molino A. B. B. \& Hanae Osera G. F. R. 2012. Desempenho e qualidade dos ovos de poedeiras comerciais alimentadas com semente de urucum (bixa orellana 1.) Moída na dieta. Veterinária e Zootecnia, 16 (4): 689-697.

Moura, A. M. A., Takata, F. N., Nascimento, G. R., Silva, A. F., Melo, T. V., \& Cecon, P. R. 2011. Pigmentantes naturais em rações à base de sorgo para codornas japonesas em postura Natural pigments on sorghum-based rations for laying Japanese quails. Revista Brasileira de Zootecnia, 40(11): 2443-2449. Doi: https://doi: 10.1590/S151635982011001100023 .

Moraleco, D. D., Valentim, J. K., Silva, L. G., Lima, H. J. D. Á., Bitencourtt, T. M., \& Dallago, G. M. 2019. Egg quality of laying hens fed diets with plant extracts. Acta Scientiarum. Animal Sciences, 41: 1-6. Doi: https:// doi.org/10.4025/actascianimsci.v41i1.43801.

Oliveira Moreno, J., Espíndola, G. B., dos Santos, M. D. S. V., Freitas, E. R., Gadelha, A. C., \& da Silva, F. M. C. 2007. Desempenho e qualidade dos ovos de poedeiras comerciais, alimentadas com dietas contendo sorgo e páprica em substituição ao milho. Acta Scientiarum. Animal Sciences, 29 (2): 1-7. Doi: https://doi.org/10.4025/actascianimsci. v29i2.220.

Pereira, A. A., Ferreira, D. A., Júnior, D. N. G., Lima, C. B., de Moura, A. S., \& de Lima Júnior, D. M. 2016. Raspa da Mandioca para Codornas em Postura. Acta Veterinaria Brasilica, 10 (2): 123-129. Doi: https:// doi.org/10.21708/avb.2016.10.2.5510.

Queiroz, E. A., Agostinho, T. S. P., Calixto, L. F. L., Queiroz, E. A., Agostinho, T. S. P., \& Calisxto, L. F. L. 2010. Níveis de farelo de urucum (Bixa orellana 1.) na dieta e seus efeitos sobre o desempenho e a intensidade de pigmentação da gema de ovos de poedeiras comerciais. Avisite, 24: 12-14. https://www.avisite.com.br/cet/img/20100706 urucum.pdf.

Rostagno, HS, Albino, LFT, Donzele, JL, Gomes, PC, Oliveira, RD, Lopes, DC, ... e Barreto, SDT. 2017. Composição de alimentos e exigências nutricionais. Tabelas brasileiras para aves e suínos, 4 .

Valentim, J. K., Bitttencourt, T. M., Lima, H. J. D., Moraleco, D. D., Tossuê, F. J. M., Silva, N. E. M., ... \& Silva, L. G. 2019. Pigmentantes vegetais e sintéticos em dietas de galinhas poedeiras Negras. Boletim De Indústria Animal, 76: 1-9. Doi: https://doi.org/10.17523/bia.2019. v76.e1438.

Valentim, J. K., Bittencourt, T. M., Lima, H. J. D. À., Barros, F. K. Q., Pereira, I. D. B., Almeida, G. R. D., \& Ziemniczak, H. M. Natural and synthetic pigments in diet of Japanese quails. 2020. Acta Scientiarum. Animal Sciences, 42: 1-7. Doi: https://doi.org/10.4025/actascianimsci. v42i1.47364. 